АГИЕВА Лемка Тугановна кандидат философских наук, ученый секретарь Ингушского научно-исследовательского института гуманитарных наук имени Ч. Э. Ахриева, Магас, Российская Федерация Lemka T. AGIEVA

Cand. Sci. (Theory and History of Culture), Academic Secretary, Ingush Research Institute of Humanities named after Ch. Ahriev, Magas, Russian Federation, 7.lenka777@bk.ru

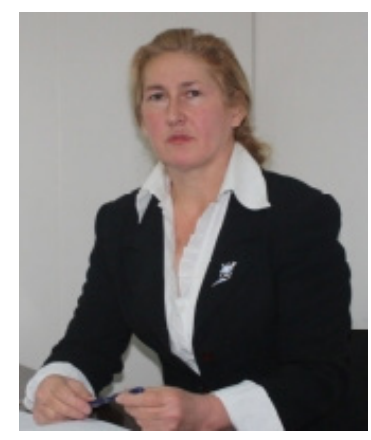

УДк 94(470.62/.67):323.269"18/19”

DOI: 10.36343/SB.2020.21.1.008

ГРНТИ 03.23.55

ВАК РФ 07.00.02

\section{Абречество как одна из форм социального протеста}

\section{Abrechestvo as a Form of Social Protest}

Феномен абречества исследуется в русле комплекса проблем, связанных с историей национально-освободительной борьбы народов Северного Кавказа. Методологической основой явился принцип эволюционного развития, примененный к анализу социальных процессов. Материалами стали архивные источники, исследования историков, данные толковых и энциклопедических словарей. Прослежена эволюция значения термина «абрек», изучено развитие самого абречества как формы социального протеста, привлечен фактографический материал, касающийся жизни одного из самых известных абреков Ингушетии - Зелимхана Гушмазукаева. Термин «абрек», первоначально означавший разбойника и изгоя, постепенно изменил смысл, приобретя значение борца за свободу против царских войск и администрации. Суть и внутреннее содержание абречества со временем эволюционировали аналогичным образом. Наличие у абречества социальной опоры обусловило вывод о том, что оно было ответом горского общества на политическое бесправие и экономические проблемы.

Ключевые слова: Северный Кавказ, Ингушетия, абрек, революция, царизм, кровная месть, горцы, Зелимхан Гушмазукаев.

Наименее изученный период национально-освободительного движения народов Северного Кавказа приходится на конец XIX начало XX в. Именно тогда, в эпоху укрепления в регионе русского царизма, здесь стало широко распространяться такое явление, как абречество, первоначально возникшее еще в глубокой древности в недрах этнических сообществ Кавказа на почве кровной мести и конфликта с обществом из-за нарушения социальных и нравственных устоев его отдельными членами с последующим их изгнанием. Этому социально-бытовому явлению сопутствовал целый комплекс социальных, быто- 


\section{ก. Т. АГИЕВА • АБРЕЧЕСТВО КАК ОДНА ИЗ ФОРМ СОЦНАПВНОГО ПРОТЕСТА}

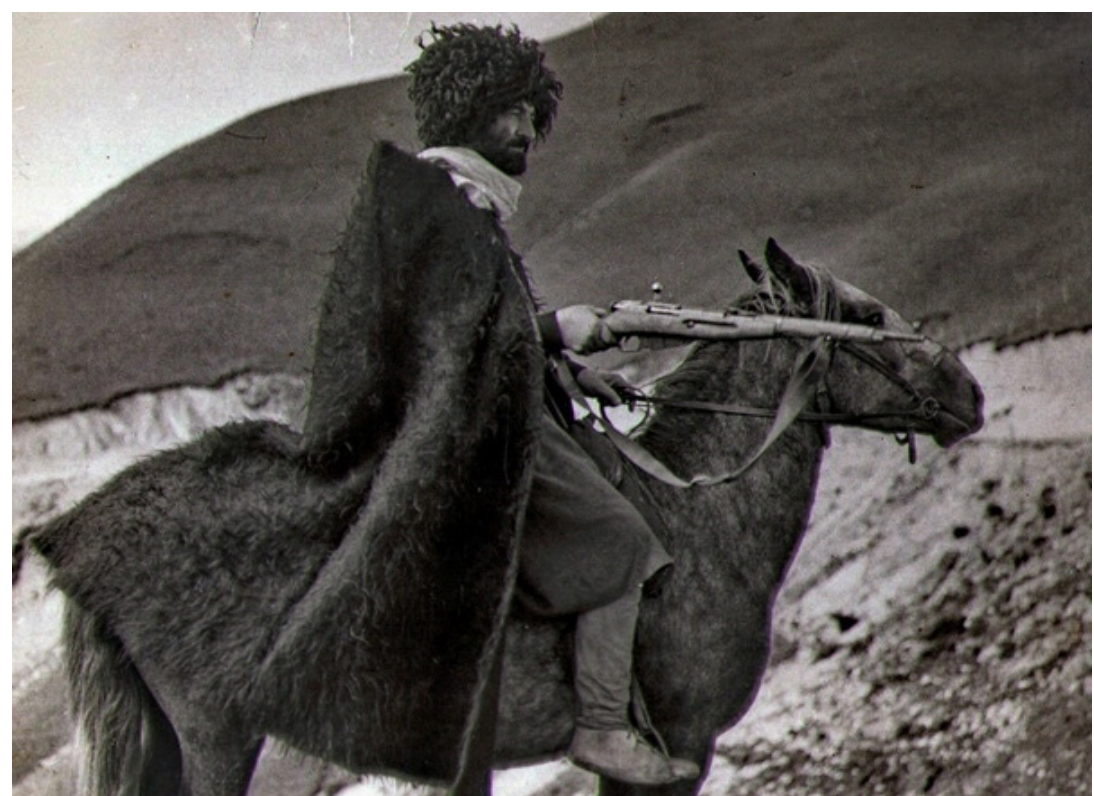

Верховой горец в бурке, с кавалерийским карабином системы Мосина-Нагана в руке. Именно так в начале ХХ столетия выглядели кавказские абреки

вых и экономических проблем, обусловленных особенностями процесса исторического развития этноса. Формирование абречества в условиях аграрно-общинного быта можно связать также с долгим отсутствием государственности в обществе, необходимостью защиты рода и членов семьи от нападения со стороны.

Историк и публицист Р.Х. Агуажба отмечал: «...одной из форм сопротивления царизму было абречество: на карательные экспедиции царских генералов, даже после покорения Кавказа, горцы отвечали стремительными и дерзкими акциями, приводившими в трепет военную администрацию Кавказа» [5, с. 130-134].

Многие становились абреками по трагическому стечению обстоятельств. Исследователи считают, что это были беглецы, уходящие в горы от возмездия, или, напротив, для того, чтобы совершить это возмездие. Очень часто они делились похищенным с бедняками, семьями без кормильцев. В абреки уходили даже князья, проштрафившиеся в своем обществе. Абречество было настолько емким понятием, что, объясняя его, каждый мог предлагать свой ракурс, придавая нужную направленность.

Приход России в регион в XVI в. и затяжная Кавказская война XIX в. добавили образу разбойников еще более страшные чер- ты - военных преступников, разорявших и сжигавших крепости и станицы, сеявших смерть. Именно такими предстают абреки во многих трудах российских военных и интеллектуалов, посвященных событиям на Кавказе [4, с. 29; 23]. Даже в середине 1930-х гг. А. М. Горький, оценивая в том числе и историографическую ситуацию, сложившуюся к тому времени, говорил о нехватке объективной информации, связанной, в частности, с социальными потрясениями: «...что эти явления у нас еще не исследованы,- не знаем ни архивов старых, мы не знаем вообще того, что делалось. Судебные архивы того времени могли бы показать нам очень многое... В этом разбойничестве были элементы бунта социального» [6, с. 497].

Термин «абрек» был распространен на Северном Кавказе: в Ингушетии - «эбарг», в Чечне - «обарг», в Грузии - «абраг», в Осетии - «абыраег», в Абхазии - «абрагъ», в Азербайджане - «гачаг», у адыгов - «хеджрет». О первых абреках стало известно XVI в.

Само слово «абрек» восходит к иранскому «бродяга, грабитель» (перс. aparak «бродяга») [22, с. 17] и, вероятно, изначально имело лишь незначительный отрицательный оттенок. Негативную коннотацию оно приобрело уже в XIX в., во время Кавказской войны, когда через черкесский язык попало в русский. Судя по схожим определениям, приведенным в словаре Ф.-Э. Г. Толля (1863) [19, с. 9], и второму изданию словаря В.И. Даля (1880), слово «абрек» практически утратило свое «благородное» значение. В частности, в «Толковом словаре живого великорусского языка» абрек определяется как «отчаянный горец, давший срочный обет или зарок не щадить головы своей и драться неистово, также беглец, приставший для грабежа к первой шайке» [9, c. 2]. Автор статьи в словаре Брокгауза и Ефрона утверждает, что «у кавказских горцев этим именем называют человека, принимающего на себя обет избегать всяких жизненных удо- 
вольствий и быть неустрашимым во всех боях и столкновениях с людьми». [3, с. 2]. Немного позднее, в XX в., значение слова «абрек» опять меняется, на этот раз в сторону романтизации: абреками стали называть «благородных кавказских разбойников» [2, с. 7].

Дореволюционный специалист в области обычного права Ф. И. Леонтович, исследуя адаты горских народов Северного Кавказа, следующим образом охарактеризовал социальный статус абреков: «По своему положению абреки были бездомные бродяги. Юридическое положение абрека выказывалось в полной его беззащитности и бесправности» [12, с. 360$]$.

Словарь русского языка С.И. Ожегова, первое издание которого увидело свет в 1949 г., содержит совершенно иную дефиницию понятия «абрек»: «...в период присоединения Кавказа к России: горец, участвующий в борьбе против царских войск и администрации» $[18$, с. 18]. Наконец, в Большой Советской энциклопедии (3-е издание, 1970 г.) указывается, что в эпоху обоснования русского царизма на Северном Кавказе абреками стали называть и всех тех, кто вел одиночную борьбу против царизма и установленного им режима. Среди последних известны: Зелимхан Гушмазукаев из Харочоя, Саламбек Гороводжев из Сагопши и др. [1, с. 29].

В этой связи Ю.В. Хоруев утверждает, что во всех толкованиях термина «абрек» наблюдается смысловое сходство и расхождения; подчеркиваются какие-то новые черты и оттенки, что значительно обогащает его семантику и делает феномен более многогранным и разноплановым. В разных трактовках понятия ясно прослеживается их связь с историческим временем, в котором жили и действовали абреки. Менялись эпохи, а с ними и поведение этих людей. Неизменным после завоевания Кавказа оставалось одно - борьба с русской властью, ее администрацией и режимом [20, с. 114]. Словом, абреками стали называть всех тех, кто самостоятельно вел борьбу против установившегося на Кавказе царского режима.

Изначально возникнув как результат нарушения норм обычного права теми или иными членами общины, племени, семьи и т.д., ин- ститут абречества претерпел на протяжении веков определенные изменения и приобрел новое содержание. Первоначально абрек (инг. «эбарг») был изгоем этого сообщества и вел жизнь одинокого бездомного бродяги. Естественно, целью его жизни, главным образом, было воровство, и ему необходимо было выжить в одиночестве. Настоящие абреки - изгнанники и отшельники, ставшие таковыми в силу самых разных причин и обстоятельств, в число которых могли входит кровная месть или оговор в совершении тяжкого преступления, что влекло за собой незаслуженную кару властей.

Впоследствии абреки являлись активно протестующей частью местного населения, не принявшей власть царизма, считавшей ее чужой для себя,- властью, с которой с самого начала ее появления в крае, представители этой части общества связывали все свои беды и страдания из-за ограничения ею их прав и свобод. Все другие преступавшие закон лица - просто воры, грабители и разбойники, на которых механически было перенесено название абреков. Главное различие между настоящими абреками и разбойниками состоит в несхожести мотивов поведения. Разбойники для достижения корыстной цели не останавливались ни перед чем: грабили, убивали, насиловали. Абреки - борцы за справедливость - должны были также прибегать к насилию и грабить, не имея других источников к существованию. Ограбление у абреков носило избирательный характер, и средства, приобретенные криминальным путем, шли, главным образом, на приобретение оружия, боеприпасов к нему, на покупку одежды, еды; остальное раздавали нуждающимся, особенно тем семьям, чьи кормильцы отбывали сроки в тюрьме. В отличие от бандитских вылазок, это были грабежи, силовые отъемы имущества без покушения на жизнь, если можно было обойтись без этого, если ничто не угрожало собственной жизни абреков и не сопровождалось отчаянным сопротивлением со стороны жертвы.

Автор книги «Разбои на Кавказе» В. Козачковский, прослуживший более трех десятилетий в тюремной администрации и надзорных ведомствах Терской области, считал, 
что «разбои на Кавказе берут свое начало со времени его покорения» и называл одну из причин абречества или разбойничества - казенное, бездушное отношение власти к тем, кто без всякого умысла, а то и совершенно случайно совершил противоправное действие. В. Козачковский также считал, что «разбойников-злодеев, рецидивистов немного: большинство же случайные; разбойники нередко даже поневоле. Одни из них жертвы темперамента, другие аффекта, третьи жертвы народных обычаев, а нередко и людской несправедливости» $[11$, с. 3$]$.

К первому десятилетию XX в. «разбои» на Кавказе приняли столь угрожающие масштабы, что феноменом, присущим только горцам,- абреками - заинтересовались даже в Государственной Думе. На одном из заседаний был заслушан доклад начальника Терской области, в котором, в частности, утверждалось: «Создалось положение, при котором промышленность и сельское хозяйство начали приходить в упадок, так как работать спокойно и последовательно не представляется возможным». На правительство России начался массированный прессинг. Депутаты Думы, политические деятели разного масштаба, центральные газеты, с умилением писавшие ранее об абреках, дружно стали требовать «навести должный порядок на Кавказе». Было принято решение ужесточить действия кавказской администрации путем увеличения военного присутствия, снятия с должностей чиновников-либералов, проведения карательных операций в наиболее «разбойничьем» регионе - Терской области.

Вместе с тем в глазах большинства представителей северокавказских сообществ абреки были, прежде всего, борцами против притеснений, чинимых царской администрацией. Слово «абрек» «стало почетным именем и этим именем народ награждал не всякого»,- писал Асламбек Шерипов, известный революционный и общественный деятель Чечено-Ингушетии. Он также указывал на несоответствие требований, предъявляемых судебными органами Российской империи, и норм обычного права горцев, отмечая: «Преступная администрация на Кавказе и общая политика притеснения заставили многих сильных личностей из чеченцев (и вообще кавказцев) становиться на нелегальное положение. Их продолжали преследовать и для успешной борьбы с вредными элементами ввели систему „круговой поруки“. От этого возмутительного акта страдали уже лица, имевшие несчастье быть родными или просто односельчанами „преступника“. Это создавало новые кадры озлобленных людей, решавшихся на все \. ... И вот начиналась месть начальству: абреки убивали административных лиц, грабили почту, казначейства и другие правительственные учреждения. А власть еще больше налегала на мирное население... Власть терроризировала местное население, а абреки терроризировали эту власть» [21, с. 47].

Ф.И. Леонтович, изучив происхождение абречества, утверждал, в частности, что абреком становился чаще всего тот, кто был виновен в убийстве невинного, или же совершил это преступление настолько бесчестно, что его собственный род отказывался выплатить за него «цену крови» (аналог виры) и защищать его. Нормы обычного права предполагали единственным возможным исходом для такого человека изгнание из общества, уход в горы и, по сути, бродяжничество. Такой образ жизни мог быть прерван, лишь если абрек заручался поддержкой кунака, который соглашался выполнять посредническую функцию в деле примирения изгоя и изгнавшего его рода.

Кроме того, для изгнания из общины будущему абреку было необязательно совершать тяжкое преступление - стойкое неповиновение общественным нормам также считалось причиной для подобного вердикта. Ф.И. Леонтович, в частности, указывает: «...абреком делалось лицо, лишенное наследства и изгнанное из своей семьи и рода за неповиновение отцу и вообще старшему в роде и другие поступки, влекшие для рода необходимость частой уплаты пеней за своего беспокойного члена, который в таких случаях обыкновенно изгонялся из рода» [13, с. 359-360].

Очень характерным в этом отношении является пример жителей аула Кок (Кек) в Горной Ингушетии в начале XX в. Из этого аула ведет свое начало род Кокурхоевых. Абрек Зелимхан Харачоевский был принят с семьей 


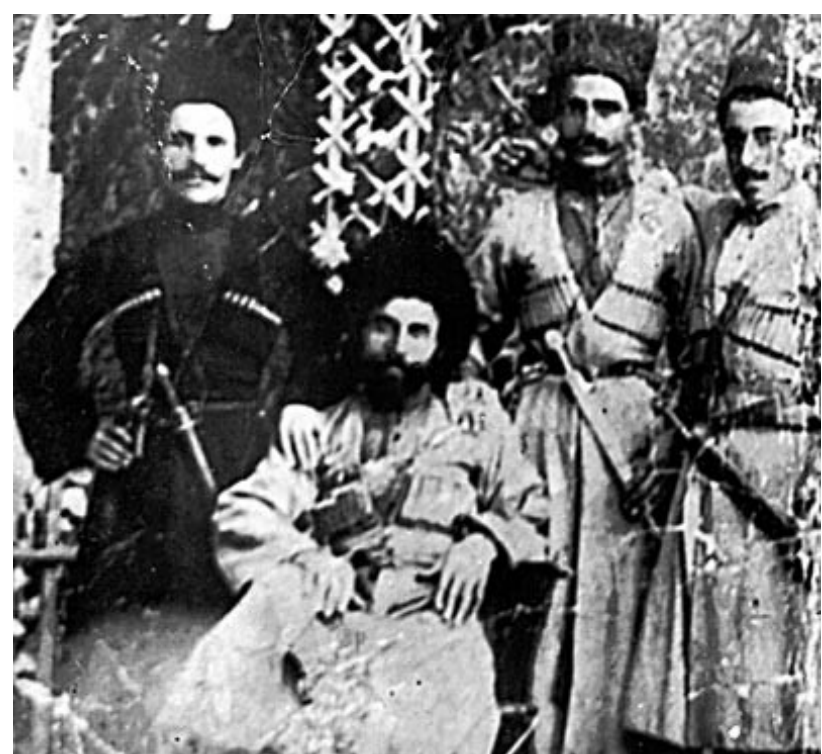

Абрек Зелимхан Харачоевский (сидит) со своими товарищами

\section{Komer e romm:}

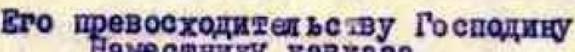
Have стнику кавказа.

\section{Оахичиальое ваявиение}

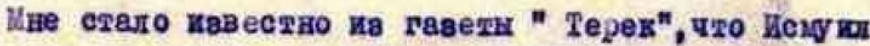

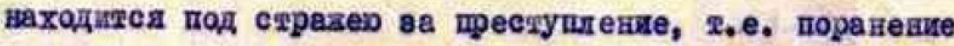

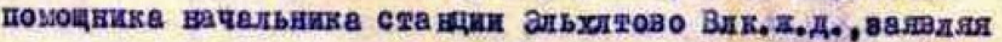

- том, чуо пресушт ене отвечает не

венио я через ограбление касси, но не удалось.

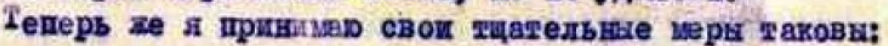

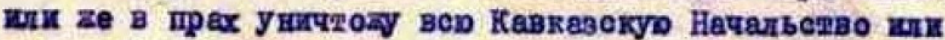

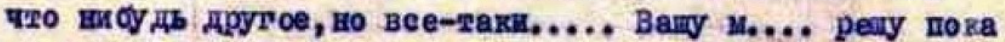

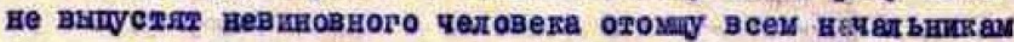

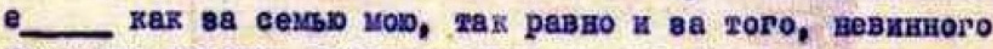
человека недедсь доказать пока не овободян их под страхи. 1912 год мара 7 дня Велиосан.

\section{I.

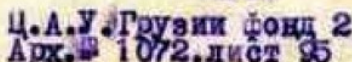

$$
\text { С поди инанм верно/ростис ь/ }
$$
Ileugrs

Копия с копии официального заявления Зелимхана Харачоевского 7 марта 1912 г. 0 coc $\sigma 65-$

о всем законам кавказского гостеприимства иначе мы ваш аул разорим и вас всех сошлем в Сибирь». Мудрые старики решили перенести все тяготы и ссылку, чем позор.

Действительно, если бы этот род поступил иначе, до сих пор народ их называл бы «Хьаьша вехка Кукурхой» - «Кокурхоевцы, предавшие гостя». Они как один стали на защиту Зелимхана и его семьи, за что и были взорваны аулы Кек и Нилх. Кроме того, 360 представителей рода Кокурхоевых были сосланы в Енисейскую губернию. Этот аул до сих пор заброшен, но род Кокурхоевых сохранил свою честь. Этот достойный для подражания пример характеризует принципы гостеприимства, где страх «позора» отодвигает на второй план все иные страхи и опасения. Властям приходилось считаться с обстоятельством, что абреков население никогда не выдавало ни добровольно, ни по принуждению.

Деятельность абрека Зелимхана, мстившего царской администрации за насилие, угнетение, грабеж народа, способствовало выселению в Сибирь людей, подозреваемых в связях с ним. Дважды выселяли горных ингушей и их семейства в Сибирь за содействие Зелимхану и его друзьям, при этом особо отличился командир 3-й сотни 2-го Кубанского пластунского батальона есаул Василенко. Много известных шейхов и мулл подозревались в сочувствии и связях с Зелимханом Харачоевским. По причинам, связанным с его деятельностью, были отправлены в ссылку (в Калугу) более 30 человек.

В 1910 г. военные власти на Кавказе организовали боль- 


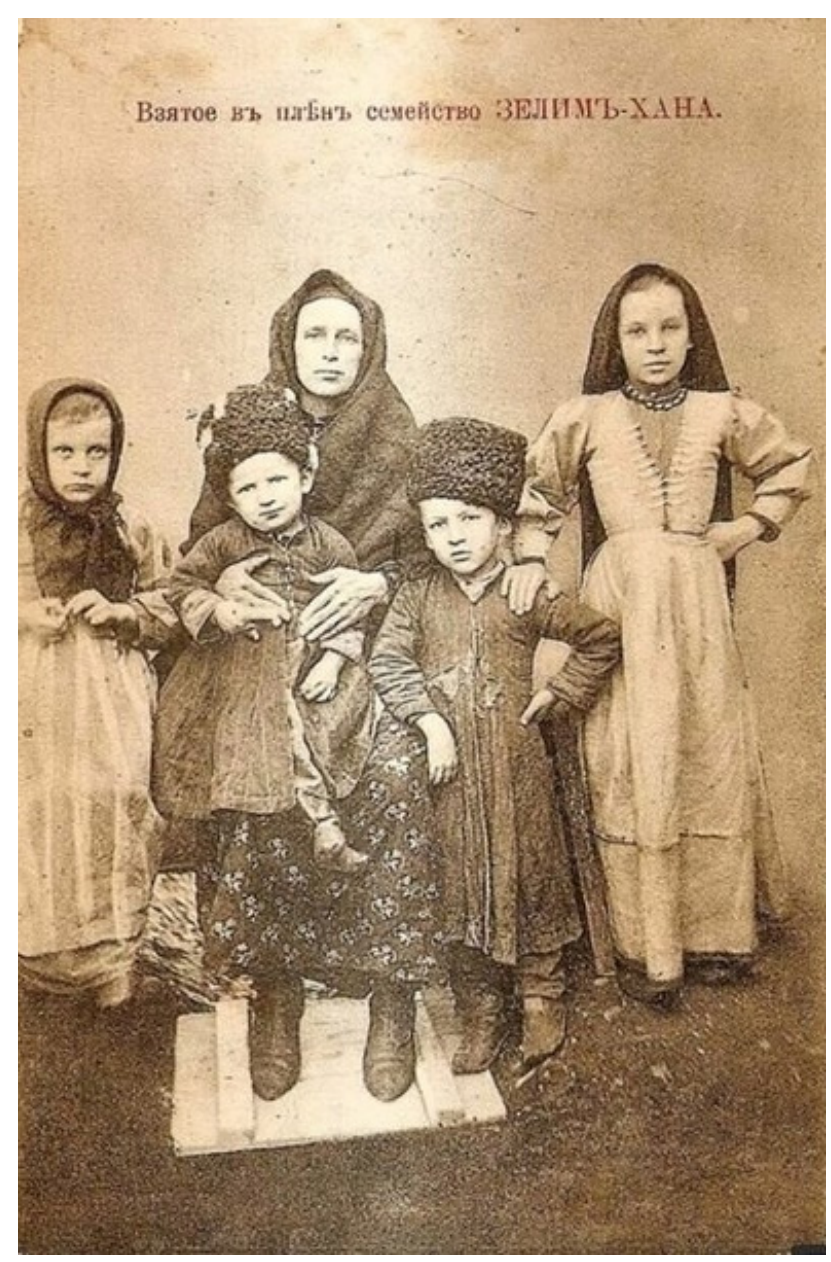

Взятое в плен семейство Зелимхана (почтовая карточка, 14 х $8.8 \mathrm{cM}$. [не позднее 1912 2.]). Издание книжного магазина А. В. Дейкарханянца, г. Владикавказ

шую экспедицию для поимки абреков и, главным образом, Зелимхана. На его поимку и ликвидацию было снаряжено в поход более двух тысяч солдат и казаков. За голову знаменитого абрека была назначена награда в 18 тысяч рублей. Рассказывают, что даже вражье ружье не стреляло, если оно было направлено на Зелимхана. По народной легенде, Зелимхан и его оружие обладали чудодейственной силой, что помогало герою долгое время оставаться неуловимым.

1913 г. стал последним годом похождений Зелимхана. Есть основания полагать, что появление такого рода абречьих легенд связано с исключительностью этого уникального явления. Несомненно, Зелимхан Гашмазукаев, Суламбек Гараводжев и другие - это незаурядные личности из народа со своими достоинствами и слабостями. Трагически оборвалась жизнь этих замечательных людей, вобравших в себя по воле обстоятельств той жестокой и противоречивой эпохи черты общественных героев, народных мстителей. Вот какую оценку дал таким героям-абрекам генерал Ольшевский: «Теперь, когда умолкли шум и азарт отчаянной борьбы, когда наша власть на Кавказе вполне упрочена, мы можем спокойно отдать дань удивления героизму и беззаветной отваге побежденного врага, честно защищавшего свою родину и свою свободу до полного истощения сил» (цит. по [17]). Такие люди действительно делали жизнь народа бессмертной. Про них ингуши говорили: «достойные мужчины - опора народа», то есть «Дика къонахий - мехка боагІий».

Подчеркиваемая отличительная черта абреков - защита бедных, обездоленных людей. Так, в преданиях повествуется, как

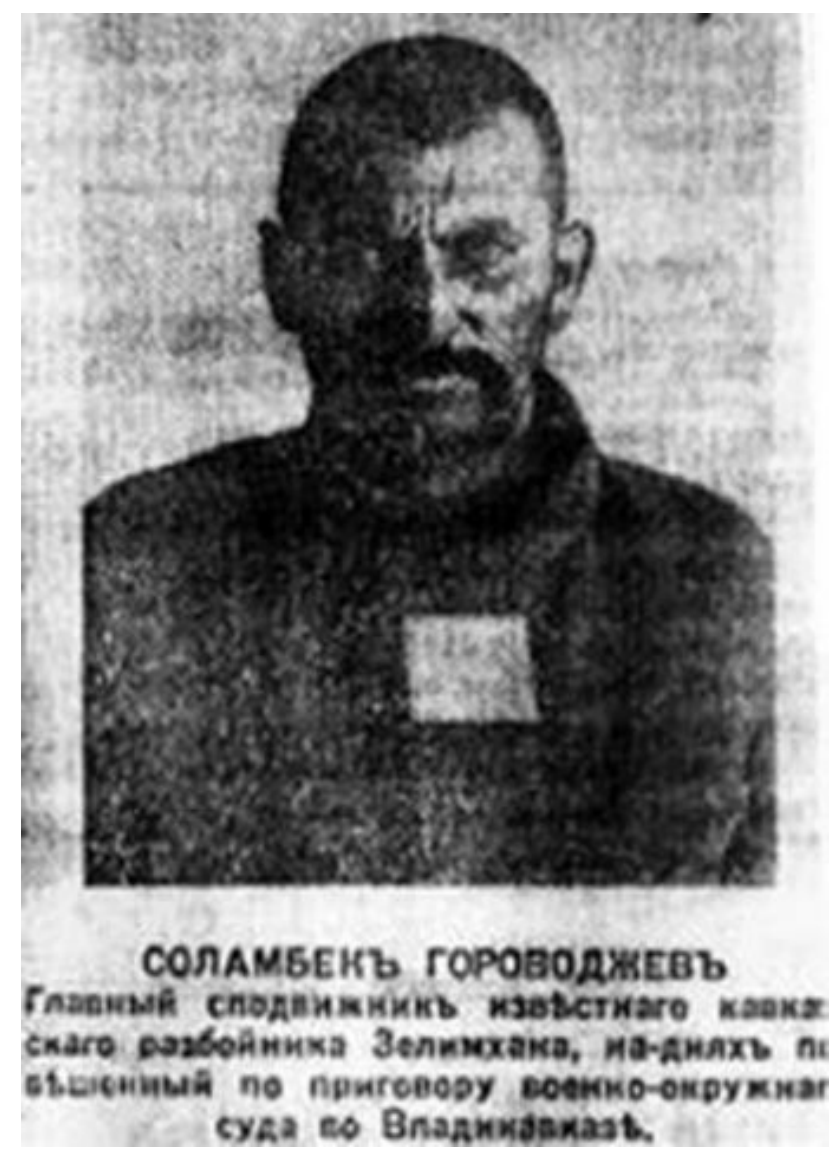

Абрек Суламбек Гараводжев (Сагопшинский)

(Соламбек Гороводжев). Фото из газеты

с пояснительной надписью («Кавказская копейка» (Баку) 1911 г., 25 августа) [?] 


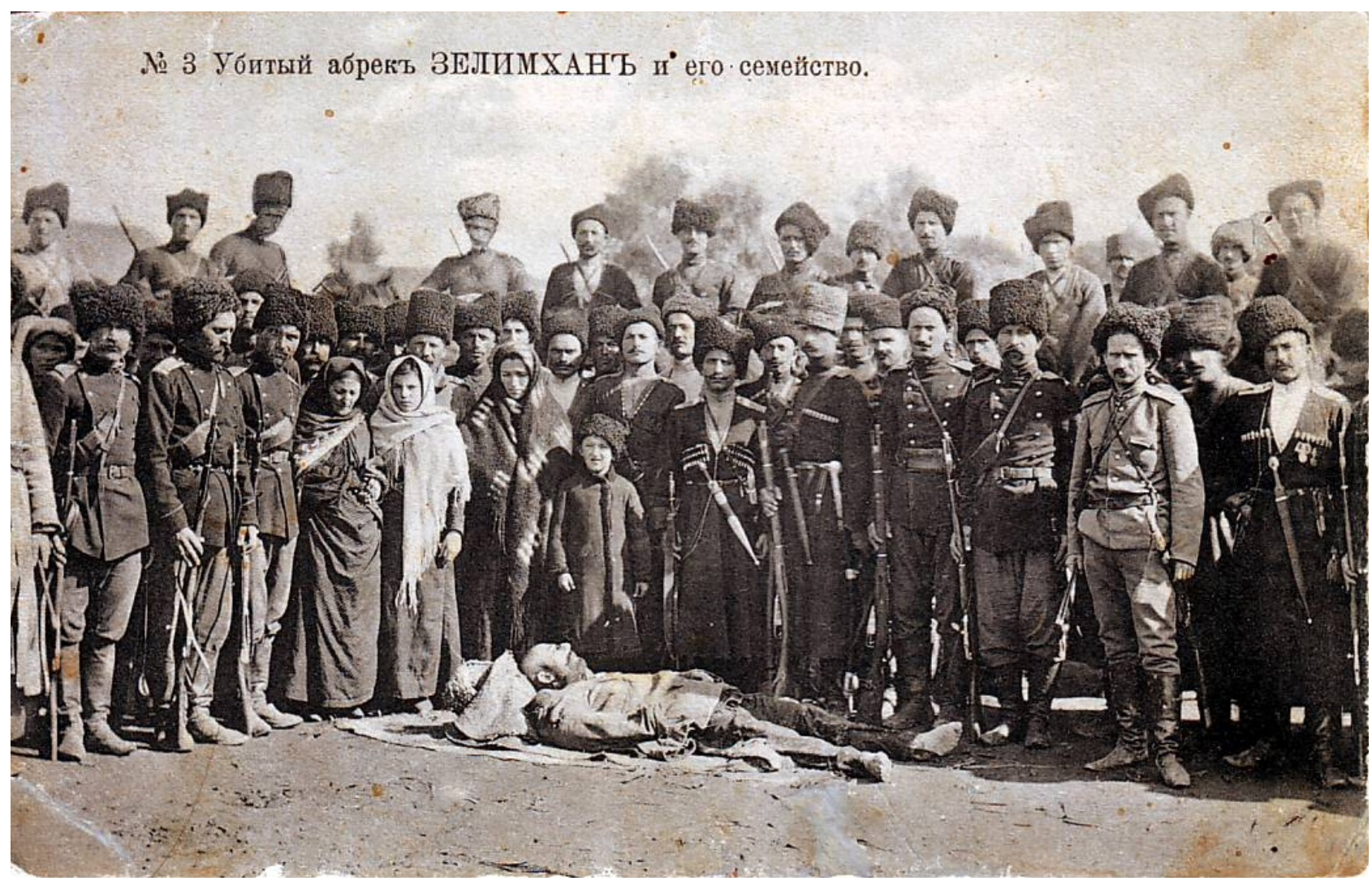

Убитый абрек Зелимхан и его семейство (почтовая карточка, 14 х 8.8 см [Шали (Терская область), 26 сентября 1913 г.]).

Зелимхан со своими сподвижниками ограбил Кизлярский банк и деньги (золото) раздал бедным людям. Доказательством тому является «Прошение», которое абрек направил 15 января 1909 г. на имя председателя III Государственной Думы октябриста Н. А. Хомякова: «Хозяйства, как сосланных, так и заключенных, совершенно разорились, жены, и дети их живут подаянием добрых людей, да тем, что я иногда уделю им из своего добра после удачного набега» [7, с. 138].

В преданиях о Зелимхане внимание концентрируется на том, что он отнюдь не грабитель, не разбойник и не вор. Показано это с помощью сопоставления подлинного Зелимхана с лжезелимханами, которые, прикрываясь именем знаменитого абрека, обирали бедных людей. Завершаются эти предания тем, что Зелимхан восстанавливает причиненный ущерб, а грабителей нещадно избивает. Справедливость становится основной чертой характера любимых народных героев. Следует также заметить, что прежде чем учинить расправу над противником, Зелимхан, как правило, писал ему письмо, в котором требовал прекратить всякое насилие, предупреждая в противном случае о печальных для него последствиях, вплоть до убийства. Каждое письмо Зелимхан скреплял собственной печатью, на которой было выгравировано его имя [8, с. 251].

Архивные документы сохранили для нас некоторые имена ингушских всадников-абреков, это: Дрис Сапралиев, Ума Оздоев, Бек-Султан Мальсагов, Егор Аушев, Баади Шибилов, Саит Манкиев, Юха Хаматханов, Таштемир Султанов, Албаст-Хаджи Антошкиев, Эльбуздко Муцольгов, Бекмурза Бахтиев, Хуни Гаракоев, Исак Арчаков, Саварби Даутов, Нагомурза Нальгиев, Тиса Бахтиев, Охруж Дарбазанов, Мида Аушев, Юнус Вдоев, Буряж Гамурзиев, Кажи Сагов, Эсмурза Арапиев, Сарали Гуражев, Исак Матиев, Алхас Медов, Атаби Картоев, Сулейман Баркинхоев, Инос Парчиев, Эдо Арсамаков, Сулейман Ведзижев, Хаджи-Мурат Беков, Абдул Парчиев, Тотре Богатырев, Хакяш Евлоев, Казбек Абиев, Заур Евлоев, Соси Гасаров, Исбаа Аушев, Пасто Богатырев, Алихан Гатиев, Гайри Арапиев, Товмурза Беков, Ар- 
таган Дакиев, Косум Мациев, Артаган Абиргов, Янырс Гарданов, Хасан Картоев и многие другие [10; 14, л. 644-645 об.; 15, л. 142; 16, л. 151-151 об.]. Ингушский конный полк явился единственным соединением в дивизии, в штате которого находились пять конных сотен. Исходя из этого необходимо отличать истинных народных заступников от обычных грабителей.

Абречество - сложное социальное явление в жизни кавказских народов. Менялись исторические эпохи, изменялась и природа абречества, его характерные признаки, модифицировалось даже само понятие, каждый раз вбирая в себя новые черты, тем более что причин и источников у этого явления на всех стадиях развития общества было предостаточно. Абреки - это не только изгнанники общества за вину. Для большинства абреков их жизнь - это яростный протест против социальной несправедливости, по причине которой они оказались вне общества, добровольно отказались от всех мирских благ и вступили в конфликт с ним, а затем и с бесцеремонным вторжением в жизнь горцев царской администрации и ее государственного аппарата. Таким образом, следует подчеркнуть, что абречество явилось ответом горского общества на политическое бесправие и тяготы экономической ситуации, сопровождавшие социальное развитие горцев Северного Кавказа в досоветский период.

Lemka T. AGIEVA

Cand. Sci. (Theory and History of Culture), Academic Secretary, Ingush Research Institute of Humanities named after Ch. Ahriev, Magas, Russian Federation,

7.lenka777@bk.ru

\section{Abrechestvo as a Form of Social Protest}

Abstract. The article is devoted to the study of the phenomenon of abrechestvo in line with a complex of scientific problems related to the history of the national liberation struggle of the peoples of the North Caucasus against the colonialist policy of the tsarist administration. The methodological basis was the principle of evolutionary development applied to social processes. The author used a set of methods inherent in historical science (historical-chronological, historical-comparative, diachronic, and others), as well as methods related to the interpretation of texts and concepts. The materials for the research were archival sources, studies of historians and data from explanatory and encyclopedic dictionaries. The term abrek is analyzed in detail, its variations in the languages of different peoples of the North Caucasus are given. Further, the author traces the evolution of the meaning of this concept in the Russian language for more than 120 years-from the dictionaries of the mid-19th century to the last edition of the Great Soviet Encyclopedia. The development of abrechestvo as a phenomenon of social life is investigated. The factual material relating to the activities of one of the most famous abreks of Mountain Ingushetia, Zelimkhan Gushmazukaev, is involved. The author comes to the conclusion that the term abrek, originally meaning a robber and an outcast, changed its meaning over the century, acquiring, in addition to a romantic connotation, the meaning of a freedom fighter against the tsarist troops and administration. Similarly, over time, the essence and inner content of abrechestvo evolved: from a forced exile and vagrancy to activities of social protest and of fighting for justice. These ideals were supported by the majority of representatives of the North Caucasian ethnic communities, who openly supported abreks, not fearing the possible reprisals from the authorities. At the same time, public consciousness quite clearly separated true abreks from those who did evil under their name and authority. The author claims that abreks resorted to robberies only selectively and avoided murders. They used the stolen property for buying weapons, for helping the needy and families who lost their breadwinners. Abreks had society's support, which led the author to the conclusion that it was a response of the highlanders' society to political lawlessness and economic problems that constantly accompanied its development during the pre-Soviet period. 
Keywords: North Caucasus, Ingushetia, abrek, revolution, tsarism, blood feud, highlanders, Zelimkhan Gushmazukaev.

\section{Использованная литература:}

1. Абрек // Большая советская энциклопедия. 3-е изд. В 30 т. Т. 1: А-Ангоб. М.: Советская энциклопедия, 1970. С. 29.

2. Абрек // Российский энциклопедический словарь. М.: Большая Российская энциклопедия, 2001. С. 7.

3. Абрек // Энциклопедический словарь Брокгауза и Ефрона. В 86 т. Т. 1: А-Алтай. СПб.: Семеновская типолитография И.А. Ефрона, 1890. С. 41.

4. Абрек. Кавказская азбука в эссе Олега Кусова. [Электронный ресурс] // Вестник Кавказа. URL: https:// vestikavkaza.ru/articles/Abrek-Kavkazskaya-azbuka-v-esseOlega-Kusova.html (дата обращения 20.06.19);

5. Гожба Р. От Кубани до Нила расселились уходящие от родных очагов горцы // Родина. 1994. № 3-4. С. 130-134.

6. Горький А. М. О литературе. М.: Советский писатель, 1937.

7. Гатуев Дз. Зелимхан. Орджоникидзе: Северо-Осетинское. кн. изд-во., 1965.

8. Гатуев Дз. Зелимхан // Стакан шейха. Орджоникидзе: Ир, 1981.

9. Даль В. Толковый словарь живого великорусского языка. В 4 т. Т. 1: А-3. М.: Русский язык Медиа, 2007.

10. Картоев М.М. Абреки Ингушского полка Кавказской Туземной конной дивизии, 1916-1917 гг. 19 января 2017 г. // Государственный архив Республики Ингушетия. URL: http://ingarchive.ru/publikacii/abrekiingushskogo-konnogo-polka-kavkazs.html (дата обращения 20.06.19).

11. Козачковский В. Разбои на Кавказе. Очерки. Владикавказ: Электропеч. С. Казарова, 1913.

12. Леонтович Ф. И. Адаты кавказских горцев. Материалы по обычному праву Северного и Восточного Кавказа. Одесса: Тип. П. А. Зеленого, 1882. Вып. 1.

13. Леонтович Ф. И. Адаты кавказских горцев. Материалы по обычному праву Северного и Восточного Кавказа. Одесса: Тип. П. А. Зеленого, 1882. Вып. 2.

14. Российский государственный военно-исторический архив. Ф. 3530. Оп. 1. Д. 96.

15. Российский государственный военно-исторический архив. Ф. 3530. Оп. 1. Д. 134.

16. Российский государственный военно-исторический архив. Ф. 3530. Оп. 1. Д. 140.

17. Современники Русско-Кавказской войны о воинских качествах черкесов // информационно-аналитическое агентство NatPress. URL: http://www.natpressru. info/index.php?newsid=9572 (дата обращения 28.02.2019).

18. Ожегов С. И. Толковый словарь русского языка. 25-е изд., М.: ОНИКС: Мир и Образование, 2006.

19. Толль Ф. Г. Настольный словарь для справок по всем отраслям знания (справочный энциклопедический лексикон): В 3 т. Т. 1: А - Двина. СПб: издание Ф. Толля, 1863.

20. Хоруев Ю. В. Абреки на Кавказе. Владикавказ: Олимп,2011.

\section{References:}

1. Prokhorov, A.M. (ed.) (1970) Abrek. In: Bol'shaya sovetskaya entsiklopediya [The Great Soviet Encyclopedia]. 3 rd ed. In 30 Vols. Vol. 1. Moscow: Sovetskaya entsiklopediya. p. 29.

2. Prokhorov, A.M. (ed.) (2001) Abrek. In: Rossiyskiy entsiklopedicheskiy slovar' [Russian Encyclopedic Dictionary]. Moscow: Bol'shaya Rossiyskaya entsiklopediya. p. 7.

3. Brockhaus, F.A. \& Efron, I.A. (eds) (1890) Abrek. In: Entsiklopedicheskiy slovar' Brokgauza i Efrona. $V 86$ t. [Brockhaus and Efron Encyclopedic Dictionary. In 86 Vols]. Vol. 1. St. Petersburg: Semenovskaya tipolitografiya I. A. Efrona. p. 41.

4. Kusov, O. (2018) Abrek. Kavkazskaya azbuka v esse Olega Kusova. [Abrek. Caucasian alphabet in an essay by Oleg Kusov]. Vestnik Kavkaza. April. [Online] Available from: https://vestikavkaza.ru/articles/Abrek-Kavkazskayaazbuka-v-esse-Olega-Kusova.html. (Accessed: 20.06.2019);

5. Gozhba, R. (1994) Ot Kubani do Nila rasselilis' ukhodyashchie ot rodnykh ochagov gortsy [From the Kuban to the Nile, highlanders departing from their homes settled]. Rodina. 3-4. pp. 130-134.

6. Gor'kiy, A.M. (1937) O literature [About Literature]. Moscow: Sovetskiy pisatel'.

7. Gatuev, Dz. (1965) Zelimkhan. Ordzhonikidze: Severo-Osetinskoe. kn. izd-vo. (In Russian).

8. Gatuev, Dz. (1981) Zelimkhan. In: Sumenova, Z.N. (ed.) Stakan sheykha [The Glass of the Sheikh]. Ordzhonikidze: Ir.

9. Dal', V. (2007) Tolkovyy slovar' zhivogo velikorusskogo yazyka. $V 4 t$. [Explanatory Dictionary of the Living Great Russian Language. In 4 Vols]. Vol. 1. Moscow: Russkiy yazyk Media.

10. Kartoev, M.M. (2017) Abreki Ingushskogo polka Kavkazskoy Tuzemnoy konnoy divizii, 1916-1917 gg. [Abreks of the Ingush Regiment of the Caucasian Indigenous Horse Division, 1916-1917]. [Online] Available from: http:// ingarchive.ru/publikacii/abreki-ingushskogo-konnogopolka-kavkazs.html. (Accessed: 20.06.2019).

11. Kozachkovskiy, V. (1913) Razboi na Kavkaze. Ocherki [Robberies in the Caucasus. Essays]. Vladikavkaz: Elektropech. S. Kazarova.

12. Leontovich , F.I. (1882) Adaty kavkazskikh gortsev. Materialy po obychnomu pravu Severnogo i Vostochnogo Kavkaza [Adata of the Caucasian Highlanders. Materials on Customary Law of the North and East Caucasus]. Is. 1. Odessa: Tip. P. A. Zelenogo.

13. Leontovich , F.I. (1882) Adaty kavkazskikh gortsev. Materialy po obychnomu pravu Severnogo i Vostochnogo Kavkaza [Adata of the Caucasian Highlanders. Materials on Customary Law of the North and East Caucasus]. Is. 2. Odessa: Tip. P. A. Zelenogo.

14. Russian State Military Historical Archive. Fund 3530. List 1. File 96. (In Russian).

15. Russian State Military Historical Archive. Fund 3530. List 1. File 134. (In Russian). 
21. Шерипов А. Статьи и речи. Грозный: Чечено-Ингушское кн. изд-во, 1961.

22. Этимологический словарь русского языка. М: Изд-во Московского ун-та, 1963. Т. 1. Вып. 1. (А).

23. Эшба Е. Асламбек Шерипов. Грозный: Отдел народного образования Чеченской авт. обл., 1927.
16. Russian State Military Historical Archive. Fund 3530. List 1. File 140. (In Russian).

17. NatPress. (2015) Sovremenniki Russko-Kavkazskoy voyny o voinskikh kachestvakh cherkesov [Contemporaries of the Russian-Caucasian War on the Military Qualities of the Circassians]. [Online] Available from: http://www. natpressru.info/index.php?newsid=9572. (Accessed: 28.02.2019).

18. Ozhegov, S.I. (2006) Tolkovyy slovar' russkogo yazyka [Explanatory Dictionary of the Russian Language]. 25th ed. Moscow: ONIKS: Mir i Obrazovanie.

19. Toll', F.G. (1863) Nastol'nyy slovar' dlya spravok po vsem otraslyam znaniya (spravochnyy entsiklopedicheskiy leksikon): $V 3 t$. [Desk-Top Dictionary for References in All Branches of Knowledge (Reference Encyclopedic Lexicon): In 3 Vols]. Vol. 1. St. Petersburg: izdanie F. Tollya.

20. Khoruev, Yu.V. (2011) Abreki na Kavkaze [Abreks in the Caucasus]. Vladikavkaz: Olimp.

21. Sheripov, A. (1961) Stat'i i rechi [Articles and Speeches]. Groznyy: Checheno-Ingushskoe kn. izd-vo.

22. Faktorovich, T.L. (ed.) (1963) Etimologicheskiy slovar' russkogo yazyka [Etymological Dictionary of the Russian Language]. Vol. 1. Is. 1. (A). Moscow: Moscow State University.

23. Eshba, E. (1927) Aslambek Sheripov. Groznyy: Otdel narodnogo obrazovaniya Chechenskoy avt. obl. (In Russian).

\footnotetext{
Полная библиографическая ссылка на статью:

Агиева Л. Т. Абречество как одна из форм социального протеста / Л. Т. Агиева // Наследие веков. - 2020. - № 1. - С. 88-97. DOI: $10.36343 /$ SB.2020.21.1.008
}

Full bibliographic reference to the article:

Agieva, L. T. (2020) Abrechestvo as a Form of Social Protest. Nasledie vekov - Heritage of Centuries. 1. pp. 88-97. (In Russian). DOI: 10.36343/SB.2020.21.1.008 